\title{
Charakterystyka wirusa SARS-CoV-2 i potencjalne farmakologiczne sposoby leczenia
}

\section{STRESZCZENIE}

W grudniu 2019 r. w Chinach odnotowano pierwsze przypadki zapalania płuc spowodowane zakażeniem nieznanym dotychczas koronawirusem, który ze względu na swoje podobieństwo do wirusa SARS-CoV został nazwany SARS-CoV-2, a choroba przez niego wywoływana - COVID-19. Dnia 11 marca 2020 r. Światowa Organizacja Zdrowia ze względu na stale rosnącą liczbę przypadków COVID-19 ogłosiła pandemię wirusa. W tej pracy przeglądowej przedstawiamy dotychczasowe naukowe doniesienia na temat pochodzenia, obrazu klinicznego, diagnostyki, budowy, cyklu replikacyjnego SARS-CoV-2 oraz potencjalnych farmakologicznych sposobach leczenia COVID-19.

\section{WPROWADZENIE}

W dniu 31 grudnia 2019 roku w mieście Wuhan (Chiny, prowincja Hubei) wykryto zapalenie płuc spowodowane infekcją nieznanym dotąd koronawirusem nazywanym początkowo 2019-nCoV. Od lutego 2020 roku wirus oficjalnie nosi nazwę SARS-CoV-2 (ang. Severe Acute Respiratory Syndrome Coronavirus 2), a wywoływana przez niego choroba COVID-19 (ang. Coronavirus Disease 2019). Według informacji udostępnianych przez Światową Organizację Zdrowia (ang. World Health Organization, WHO), na dzień 15.04.2020 r. potwierdzono 1913916 przypadków w 184 krajach, w tym 83745 w Chinach i 162488 we Włoszech, które początkowo stanowiły jedno z głównych ognisk rozprzestrzeniania się wirusa w Europie [1]. Wystąpienie pierwszego zakażenia w Polsce notuje się na 4 marca 2020 roku. 11 marca 2020 roku postępujący wzrost zachorowań został oficjalnie mianowany pandemią, a jej skutki stanowią aktualnie problem o skali światowej dla zdrowia publicznego.

W tej pracy omówimy prawdopodobne pochodzenie, budowę i cykl replikacyjny SARS-CoV-2. Następnie opiszemy diagnostykę, objawy kliniczne oraz dotychczasowe doniesienia naukowe o potencjalnych możliwościach i strategiach terapeutycznych w leczeniu COVID-19.

\section{PODZIAŁ, POCHODZENIE I TRANSMISJA KORONAWIRUSÓW}

Koronawirusy dzieli się na cztery rodzaje: $\alpha$ - i $\beta$-koronawirusy, które są patogenne dla ssaków oraz $\gamma^{-}$i $\delta$-koronawirusy, które wywołują choroby u ptaków. Wirus SARS-CoV-2 jest siódmym z poznanych koronawirusów mogących zainfekować człowieka. Wszystkie z nich, tj. HCoV-229E, HCoV-HKU1, HCoV-NL63, HCoV-OC43 (ang. Human Coronavirus; koronawirus ludzki), SARS-CoV oraz MERS-CoV (ang. Middle East Respiratory Syndrome Coronavirus) odpowiadają za choroby układu oddechowego [2]. Wirusy HCoV-229E, HCoV-HKU1, HCoV-NL63, HCoV-OC43 są czynnikami etiologicznymi pojawiających się sezonowo, łagodnych i samoograniczających się infekcji dróg oddechowych. Wywołują one objawy grypopodobne i nie stanowią szczególnego zagrożenia dla życia [3]. Pozostałe dwa wirusy, SARS-CoV i MERS-CoV są znacznie bardziej patogenne, wykazują też więcej podobieństw do SARS-CoV-2. SARS-CoV jest odpowiedzialny za epidemię, która rozpoczęła się w 2002, a zakończyła w 2003 roku. Infekcje MERS-CoV odnotowuje się u ludzi od 2012 roku, w większości przypadków na terenie Arabii Saudyjskiej. Współczynniki śmiertelności wywoływanych przez nich chorób wynoszą około 11\% dla SARS-CoV i 35\% dla MERS-CoV [4,5]. Według danych WHO na dzień 15.04.2020 r. śmiertelność wirusa SARS-CoV-2 wynosi około $6,4 \%$ [1].

Pierwotnie rezerwuarem dla SARS-CoV i MERS-CoV były nietoperze. Ekspozycja wirusa na inne gatunki zwierząt doprowadziła do przekroczenia bariery międzygatunkowej. $\mathrm{W}$ obu przypadkach proces transmisji wirusa $\mathrm{z}$ nietoperza na człowieka obejmował nosiciela pośredniego, którymi byli łaskun palmowy

\section{Leon Pawlik,}

\section{Emilian Śpiołek,}

prof. dr. hab Jakub Fichna,

mgr inż. Aleksandra

Tarasiuk $^{\otimes}$

Zakład Biochemii, Katedra Chemii i Biochemii Medycznej, Uniwersytet Medyczny w Łodzi

https://doi.org/10.18388/pb.2020_321

๑autor korespondujący: aleksandra.tarasiuk@ umed.lodz.pl

Słowa kluczowe: SARS-CoV-2, COVID-19, chlorochina, ribawiryna, antagoniści receptora angiotensyny II

Skróty: ACE2 - konwertaza angiotensyny typu II (ang. Angiotensyn-Converting Enzyme 2), ARB - antagoniści receptora angiotensyny II (ang. Angiotensin Receptor Blockers), CLC - Chlorochina, COVID-19 - choroba koronowirusowa 2019 (ang. Coronavirus Disease 2019), IFN - Interferon, ISG - geny stymulowane przez interferon (ang. Interferon-Stimulated Genes), $\mathrm{HCoV}$ - koronawirus ludzki (ang. Human Coronavirus), SARS - koronawirus ciężkiego ostrego zespołu niewydolności oddechowej (ang. Severe Acute Respiratory Syndrome Coronavirus), SARS-CoV-2 - koronawirus ciężkiego ostrego zespołu niewydolności oddechowej 2 (ang. Severe Acute Respiratory Syndrome Coronavirus 2), MERS-CoV -koronawirus bliskowschodniego zespołu niewydolności oddechowej (ang. Middle East Respiratory Syndrome), RD - Remdesiwir, GS-5734, WHO - Światowa Organizacja Zdrowia (ang. World Health Organization)

Finansowanie (statut): Praca ze środków na działalność statutową dla Zakładu Biochemii, Katedry Chemii i Biochemii Medycznej, Uniwersytet Medyczny w Łodzi (503/1-15604/503-11-001-19-00 dla JF).

Wkład autorów: LP, ES i AT przedstawili ogólną koncepcję i ramy manuskryptu; LP, ES i AT opracowali bibliografię i napisali manuskrypt; LP stworzył ryciny; LP, ES, JF i AT poprawili manuskrypt. Wszyscy autorzy przeczytali i zatwierdzili ostateczną wersję manuskryptu. 
dla SARS-CoV i wielbłąd jednogarbny dla MERS-CoV [6,7]. Przypuszcza się, że SARS-CoV-2 podobnie jak SARS-CoV i MERS-CoV pochodzi od nietoperzy, natomiast kwestia nosiciela pośredniego nadal pozostaje $\mathrm{w}$ tym przypadku nie do końca wyjaśniona [8].

Wirus SARS-CoV-2 przenosi się drogą kropelkową. Do infekcji może dojść zarówno w wyniku bezpośredniego kontaktu z nosicielem, jak i pośredniego - poprzez styczność z otoczeniem, w którym wcześniej przebywała osoba zakażona. W swoim badaniu N. van Doremalen i wsp. [9] wykazali, że wiriony SARS-CoV-2 zawieszone w postaci aerozolu $\mathrm{w}$ środowisku o temperaturze $21-23^{\circ} \mathrm{C}$ i wilgotności względnej wynoszącej $65 \%$, po upływie 3 godzin od rozpylenia wciąż utrzymywały się $\mathrm{w}$ formie zdolnej do zakażenia. Okazało się również, że wirus SARS-CoV-2 jest w stanie przetrwać 4 godziny na powierzchni miedzianej, do 24 godzin na powierzchni kartonowej, a na powierzchni ze stali nierdzewnej lub z plastiku do 72 godzin.
BUDOWA I CYKL REPLIKACYJNY WIRUSA SARS-COV-2

Wirus SARS-CoV-2 należy do $\beta$-koronawirusów. Swoją nazwę zawdzięcza wysokiemu podobieństwu do ludzkiego wirusa SARS (82\%) oraz do występującego u nietoperzy SARS-like-CoVZXC21 [10]. SARS-Cov-2 ma genom w postaci pojedynczej nici RNA o dodatniej polarności, nukleokapsyd (zbudowany z białka $\mathrm{N}$ oraz RNA) o helikalnej symetrii oraz dwuwarstwową, białkowo-lipidową osłonkę, pochodzącą z komórki gospodarza w skład której oprócz lipidów wchodzą również wirusowe białka: osłonkowe (ang. envelope, E), błonowe (ang. membrane, M) oraz glikoproteiny $\mathrm{S}$ (ang. spike, S), które swym kształtem przypominają kolce. Te ostatnie odpowiadają za wiązanie cząstek wirusa do receptorów na błonach komórkowych gospodarza (Ryc. 1A).

Glikoproteina S składa się z dwóch podjednostek czynnościowych: S1 odpowiedzialnej za połączenie się z re-

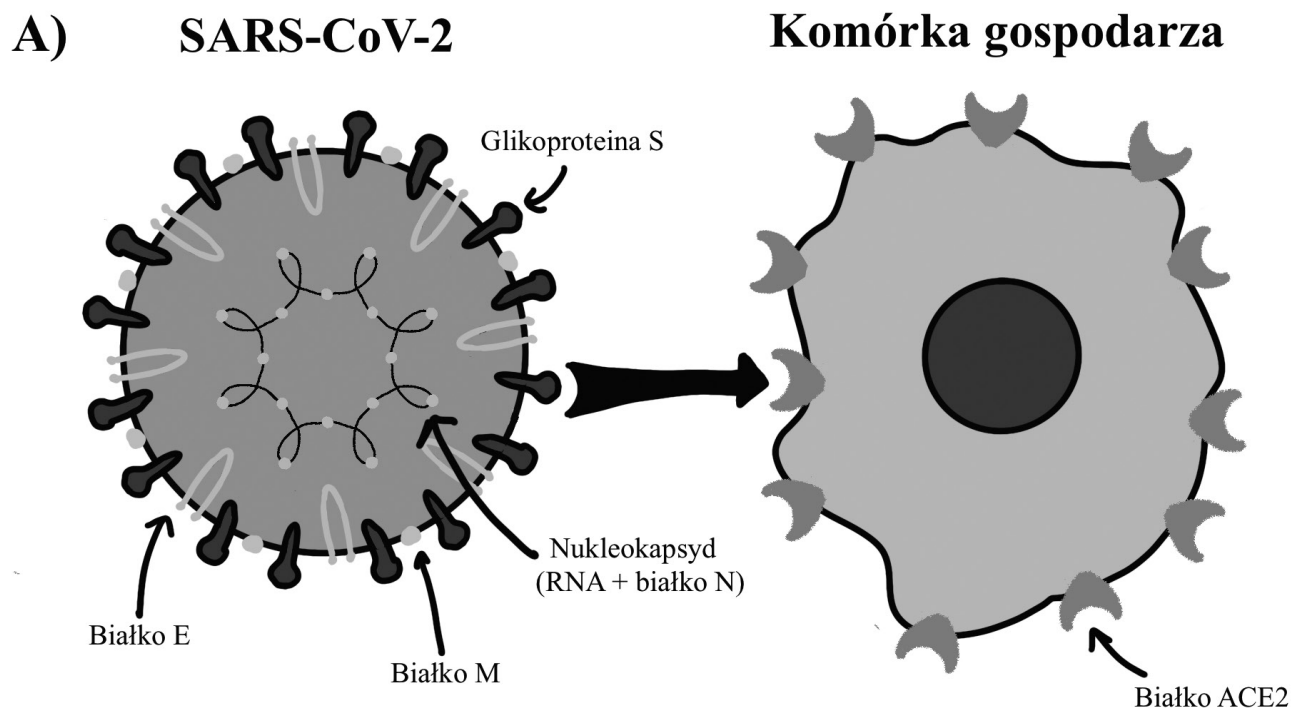

B) Terapia rozpuszczalną frakcją ACE2

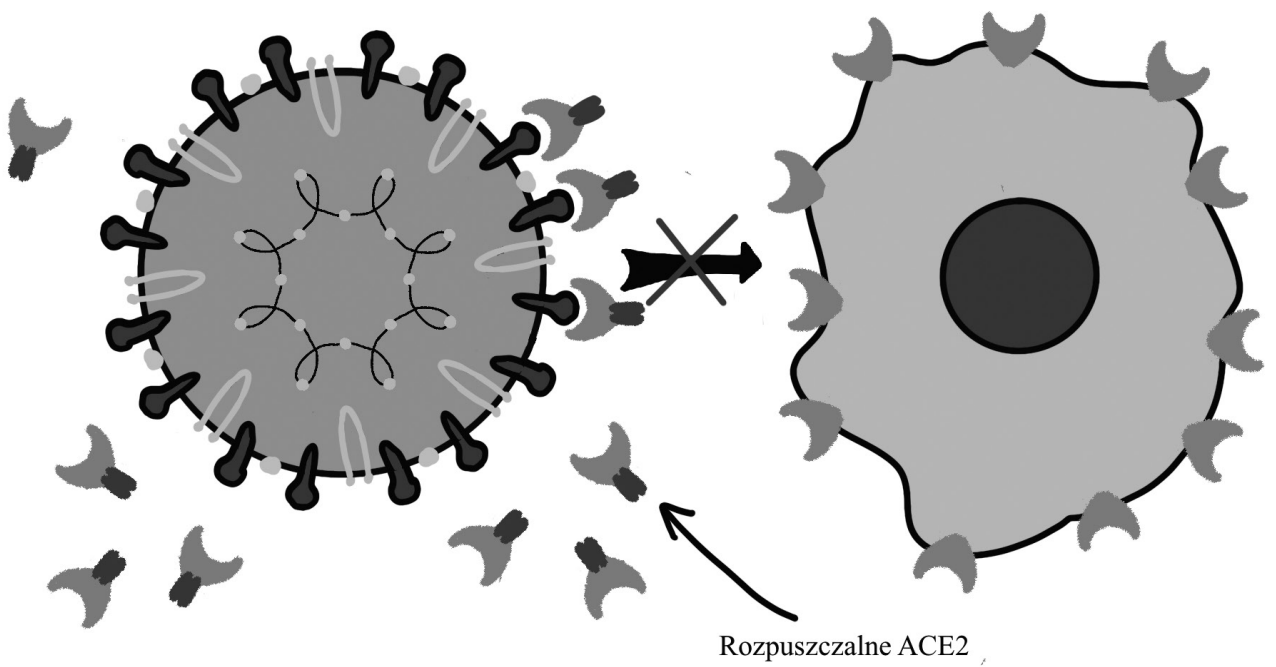

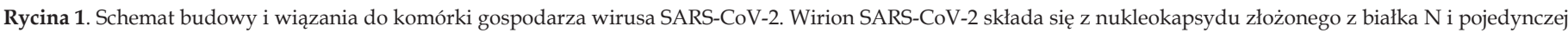

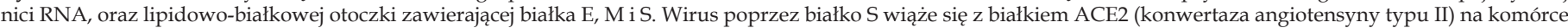

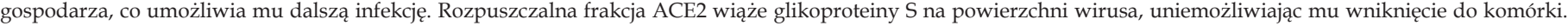
Więcej informacji znajduje się w podrozdziale „Rozpuszczalna frakcja ACE2”. 
ceptorem na powierzchni komórki gospodarza, natomiast zadaniem S2 jest fuzja osłonki wirusa z błoną komórkową. Podjednostka S2 SARS-CoV-2 wykazuje wysokie podobieństwo (99\%) do tych obecnych u ludzkiego wirusa SARS-CoV oraz dwóch wirusów SARS-like występujących $\mathrm{u}$ nietoperzy $\mathrm{w}$ przeciwieństwie do podjednostki S1 wykazującej podobieństwo na poziomie 70\% [10]. W celu zbadania możliwej krzyżowej odporności na koronawirusy Walls i wsp. [11] stworzyli pseudotypowane cząsteczki wirusowopodobne SARS S-MLV oraz SARS-CoV-2. Powstały one poprzez trasfekcję linii komórkowej HEK293T trzema plazmidami. Pierwszy zawierał geny gag/pol retrowirusa mysiej białaczki (murine leukemia virus; MLV), drugi kodował białko lucyferynę, a trzeci białko $S$ wirusa SARS lub SARS-CoV-2. W rezultacie otrzymali cząsteczki podobne do wirusa MLV posiadającą w swej otoczce białko S, a przez to wykazujące tropizm do białka ACE2. Badacze w doświadczeniu in vitro na linii komórkowej Vero E6 (linia komórkowa wywodząca się z komórek nabłonkowych nerki małpy gatunku Chlorocebus aethiops wykazująca ekspresję białka ACE2) wykazali, że przeciwciała- pozyskane z surowicy czterech myszy uprzednio immunizowanych przy użyciu białka $S$ wirusa SARS-CoV- całkowicie blokowały transdukcję cząsteczki SARS S-MLV i zmniejszyły do 10\% transdukcję SARS-CoV-2 S-MLV w porównaniu do próby kontrolnej. Doświadczenie to może sugerować, że ze względu na znaczne podobieństwo między glikoproteinami $S$ wirusa SARS-CoV oraz SARS-CoV-2, wytworzenie odporności przeciwko jednemu $\mathrm{z}$ tych wirusów może uniemożliwić lub utrudnić infekcję drugim.

W przypadku wirusów SARS-CoV oraz SARS-CoV-2 receptorem błonowym na komórce gospodarza jest konwertaza angiotensyny typu II (ang. angiotensin-converting enzyme 2, ACE2). W ustroju ACE2 przekształca angiotensynę II w angiotensynę 1-7, która rozszerza naczynia krwionośne oraz wykazuje działanie przeciwzapalne, przeciwzakrzepowe i antyproliferacyjne [12]. W płucach, w warunkach fizjologicznych, ACE2 ulega ekspresji na pneumocytach typu I oraz II. Z badań przeprowadzonych przez Zhao i wsp. [13] wynika, że w przebadanej populacji (n=8) ACE2 ulega ekspresji na około 0,64\% komórek w tkance płucnej (u mężczyzn na 1,66\%, u kobiet na 0,41\%), z czego 83\% znajduje się na pneumocytach typu II. Poza tym, obecność ACE2 stwierdzono również w sercu, nerkach oraz przewodzie pokarmowym[14]. Występowanie ACE2 na enterocytach może po części tłumaczyć wystąpienie u niektórych pacjentów z COVID-19 objawów takich jak: nudności, biegunka i wymioty oraz obecność materiału genetycznego wirusa w kale (co prawdopodobnie wskazuje na możliwość zakażenia drogą fekalno-oralną) [15].

Wirus SARS-CoV-2, po połączeniu się glikoproteiny $S$ z ACE2, wnika do komórki na drodze endocytozy. W zakwaszonych endosomach, przy udziale m.in. katepsyny L oraz śródbłonowej proteazy serynowej 2 (ang. Transmembrane serine protease 2, TMPRSS2), dochodzi do cięcia enzymatycznego białka $S$ w dwóch miejscach, co umożliwia materiałowi genetycznemu wirusa wniknięcie do cytoplazmy gospodarza. Następnie dochodzi do ekspresji dwóch poliprotein- ppla i pplab, które są enzymatycznie przecinane przez kodowane przez koronawirusy proteazy: papaino- podobną (ang. papain-like protease) i serynową, co prowadzi do powstania niestrukturalnych białek wirusa (ang. nonstructural proteins, NSPs) 1-16. NSPs tworzą kompleks replikazo-transkryptazy, co umożliwia wirusowi powielenie materiału genetycznego oraz syntezę mRNA używanego następnie jako matryca do translacji białek strukturalnych S, E, M oraz N. Białka te zostają przetransportowane do retikulum endoplazmatycznego, a następnie do dodatkowego kompartmentu ERGIC (ang. endoplasmic reticulum-Golgi intermediate compartment; jest to przedział pośredni zlokalizowany pomiędzy siateczką śródplazmatyczną a cysternami cis Aparatu Golgiego), gdzie po wniknięciu wirusowego RNA dochodzi do tworzenia dojrzałych wirionów. Wiriony są transportowane w pęcherzykach wydzielniczych w pobliże błony komórkowej, gdzie dochodzi do ich egzocytozy. Co ciekawe, część z wyprodukowanych białek S, które nie zostały wykorzystane do budowy wirionu, są transportowane na powierzchnię błony komórkowej, co umożliwia połączenie kilku sąsiednich komórek i tym samym łatwiejszą propagację infekcji bez wychodzenia do przestrzeni pozakomórkowej i alarmowania układu odpornościowego [16].

\section{DIAGNOSTYKA I OBJAWY INFEKCJI SARS-COV-2}

Aktualnie powszechnie stosowanymi narzędziami diagnostycznymi, poza badaniem lekarskim, są m.in. techniki biologii molekularnej oraz tomografia komputerowa (TK) [17].

Materiałem, w którym bada się obecność wirusa SARS-CoV-2 są wydzieliny pozyskiwane z dróg oddechowych pacjenta (popłuczyny oskrzelowo-pęcherzykowe, ślina, wymaz z gardła). Na obecną chwilę głównym badaniem rekomendowanym przez WHO i Centra Kontroli i Prewencji Chorób (ang. Centers for Disease Control and Prevention, CDC) jest test z zastosowaniem reakcji łańcuchowej polimerazy z odwrotną transkryptazą w czasie rzeczywistym (ang. Real-time RT-PCR) pozwalający na wykrycie RNA wirusa w badanej próbce. Metoda opiera się na syntezie cDNA na podstawie wirusowego RNA za pomocą enzymu odwrotnej transkryptazy. Uzyskane cDNA służy jako matryca do reakcji Real-time PCR. Dużą zaletą reakcji Real-time RT-PCR jest możliwość jednoczesnej analizy oraz wizualizacji produktu w trakcie trwania reakcji oraz duża czułość techniki, umożliwiająca efektywne oznaczanie mniejszych ilości RNA (w porównaniu do innych stosowanych powszechnie metod). Jednymi z genów powielanych w testach RT-PCR są geny " $\mathrm{E}$ " i "RdRP" kodujące odpowiednio: białko osłonkowe oraz enzym RNA-zależnej polimerazy RNA. Grupy badaczy wciąż pracują nad metodami mogącymi udoskonalić wykrywanie infekcji SARS-CoV-2 [18]. Przykładem może być test opracowany przez Li Z. i wsp., wykrywający obecność przeciwciał IgM i IgG przeciwko SARS-CoV-2 we krwi. Umożliwia on wykrycie infekcji na wszystkich etapach zaawansowania w ciągu 15 minut z 88,66\% czułością i 90,63\% swoistością [19].

Zmiany w miąższu płuc powodowane przez SARS-CoV-2 mogą zostać uwidocznione w TK. W badaniu przeprowadzonym przez Han i wsp. [20] 108 pacjentów (38 mężczyzn i 70 kobiet) w wieku 21-90 lat poddano obra- 
zowaniu TK. W momencie wykonywania zdjęcia czas od pojawienia się objawów wynosił od 1 do 3 dni. U 70 badanych (65\%) zmiany obejmowały 2 lub więcej płatów, 97\% zmian zlokalizowanych było w obwodowych częściach płuc. Średnica większości zmian (63\%) była większa niż 1 cm. W 86\% przypadków widoczne były zmiany o charakterze tzw. "matowej szyby” (ang. ground-glass opacity, GGO), czyli zacienienie miąższu płuca świadczące o zwiększeniu gęstości tkanki. U żadnego z badanych nie zaobserwowano powiększenia śródpiersiowych i wnękowych węzłów chłonnych, pogrubienia czy wysięku opłucnowego. W celu przyśpieszenia i większego zautomatyzowania diagnostyki COVID-19 opartej na TK Gozes i wsp. [21] opracowali oprogramowanie oparte na sztucznej inteligencji, które w ciągu około 20 sekund analizuje obraz i wykrywa chorobę z bardzo wysoką czułością (98,2\%) i swoistością (92,2\%). Objawy pacjentów z COVID-19 nie są swoiste dla tej choroby, co oznacza, że rozpoznanie musi być oparte również na informacjach pozyskanych z badań dodatkowych (metody biologii molekularnej, TK). To podkreśla jak istotny dla powstrzymania pandemii jest rozwój metod diagnostycznych.

COVID-19 charakteryzuje się występowaniem objawów grypopodobnych. Podział dolegliwości pacjentów z infekcją SARS-CoV-2 ze względu na częstość występowania został przedstawiony w pracy przeglądowej Chih-Cheng Lai i wsp. [22], w której zestawiono wyniki badań opisujących objawy kliniczne łącznie 278 dorosłych chorych. Najczęstszym symptomem była gorączka $(\mathrm{n}=258 ; 92.8 \%)$, następnie kaszel (n=194; 69,8\%), duszności ( $n=96 ; 34,5 \%)$, bóle mięśni $(n=77 ; 27,7 \%)$, ból głowy $(n=20 ; 7,2 \%)$ i biegunka $(n=17$; $6,1 \%)$.

\section{POTENCJALNE FARMAKOLOGICZNE METODY LECZENIA COVID-19}

\section{CHLOROCHINA}

Chlorochina (CLC) jest powszechnie używaną pochodną chinoliny znaną już od 1934 roku. Pierwotnie była stosowana jako lek przeciwko malarii [23]. Oprócz swoich właściwości pierwotniakobójczych CLC ma działanie immunomodulujące, dzięki czemu zaczęto ją i jej hydroksylowaną pochodną - hydroksychlorochinę (HCLC) stosować w leczeniu chorób autoimmunologicznych, np. w reumatoidalnym zapaleniu stawów [24].

CLC i HCLC są słabymi zasadami, dzięki czemu z łatwością mogą gromadzić się w organellach komórkowych o niskim $\mathrm{pH}$, m.in. w aparacie Golgiego, lizosomach oraz endosomach. Ze względu na zmianę pH w tych strukturach komórkowych CLC zakłóca funkcjonowanie wielu enzymów, m.in. kwaśnych hydrolaz (rozkładających kwasy nukleinowe, białka oraz tłuszcze) oraz hamuje potranslacyjną obróbkę nowopowstałych białek. Przeciwwirusowe właściwości CLC wynikają prawdopodobnie z kilku mechanizmów. Po pierwsze, zaburzenie działania enzymów hydrolitycznych $\mathrm{w}$ endosomach uniemożliwia wirusom ich wyjście do cytoplazmy gospodarza. Po drugie, dla niektórych wirusów niezbędna jest potranslacyjna obróbka glikoprotein otoczki wirusowej przez glikozylotransferazy, które do swojego funkcjonowania w endosomach i aparacie Golgiego wyma- gają niskiego pH [24]. Dodatkowo, HCLC obniża produkcję cytokin prozapalnych (np. TNF-a) oraz ich receptorów, m.in. poprzez blokadę szlaków sygnałowych: p38, JNK oraz NF-kB [25].

W doświadczeniu in vitro (na liniach komórkowych Vero E6) Wang i wsp. [26] wykazali, że CLC ma działanie hamujące na rozwój infekcji wirusem SARS-CoV-2019 zarówno na etapie wczesnej, jak i późnej infekcji. CLC ma również działanie immunomodulujące, co może synergistycznie wzmocnić jej właściwości przeciwwirusowe in vivo. CLC po podaniu doustnym jest szeroko dystrybuowane $\mathrm{w}$ całym organizmie, w tym także w płucach [27]. Stężenie CLC przy którym 90\% SARS-CoV-2 ulegało inaktywacji w komórkach Vero E6 wynosiła 6,9 $\mu \mathrm{M}$. Takie stężenie jest możliwe klinicznie do osiągnięcia przy dawce $500 \mathrm{mg}$ podawanej doustnie dwa razy dziennie [26]. Yao i wsp. [28] dzięki badaniom in vitro i opartym na fizjologii modelom farmakokinetycznym obliczyli, że podawanie doustnie siarczanu HCLC w dawce $400 \mathrm{mg}$ dwa razy dziennie, a następnie w dawce podtrzymującej: $200 \mathrm{mg}$ dwa razy dziennie przez 4 dni jest trzy razy bardziej skuteczne niż $500 \mathrm{mg}$ CLC dwa razy dziennie przez 5 dni. Rozpoczęte w ponad 10 szpitalach w Chinach badania kliniczne dotyczące skuteczności oraz bezpieczeństwa stosowania CLC w leczeniu COVID-19 [29] wykazały, że u ponad 100 pacjentów (stan z 18.02.2020) stosowanie CLC złagodziło przebieg zapalenia płuc, poprawiło obraz radiologiczny oraz skróciło czas trwania choroby.

\section{REMDESIWIR}

Analogi nukleotydów są wykorzystywane w terapiach antywirusowych ze względu na ich podobieństwo strukturalne do naturalnych substratów w syntezie DNA i RNA. Mechanizm ich działania może polegać między innymi na inhibicji polimerazy oraz zablokowaniu możliwości przyłączenia kolejnego nukleotydu do syntezowanego łańcucha co powoduje jego przedwczesną terminację. Dotychczasowo stosowane pochodne nukleotydów nie są skuteczne podczas infekcji koronawirusowych głównie za sprawą występującej u tej grupy egzonukleazy [30]. Remdesiwir (GS-5734; RD), to środek przeciwwirusowy o szerokim spektrum działania, który został pierwotnie wyprodukowany jako lek na infekcje wirusem Ebola [31]. RD jest prolekiem, który po ufosforylowaniu w komórce przekształca się w aktywną postać: GS-441524, która uniemożliwia zakończenie syntezy łańcucha RNA oraz zmniejsza skuteczność działania egzonukleazy[30,32]. RD wykazał właściwości przeciwwirusowe przeciw wirusom RNA (SARS, MERS, Ebola) zarówno w hodowlach komórkowych, jak i w badaniach in vivo [33]. Ponadto RD podano dożylnie pierwszemu choremu na COVID-19 w Stanach Zjednoczonych [34]. Ze względu na obiecujące wyniki badań przedklinicznych 12.02.2020 r. rozpoczęto $\mathrm{w}$ Chinach randomizowane, podwójnie zaślepione badania kliniczne mające na celu ocenę skuteczności i bezpieczeństwa stosowania RD u pacjentów z ciężką [35] ( $n=453)$ oraz łagodną [36] (n=308) postacią COVID-19. Pacjentom podawano dożylnie [37]. Badania zostaną prawdopodobnie zakończone na prze- 
łomie kwietnia i maja 2020 i dopiero ich wyniki pozwolą ocenić kliniczne zastosowanie RD.

\section{INTERFERONY TYPU I}

Interferony (IFN) typu I to grupa cytokin do której należą m.in. IFN- $\alpha$, IFN- $\beta$. Związki te są zaangażowane w ochronę przeciwwirusową i wydzielane są przez komórki układu odpornościowego w reakcji na wykrycie przez receptory rozpoznające wzorce materiału pochodzenia wirusowego. W następstwie połączenia IFN typu I z receptorem IFNAR (obecnym na powierzchni większości komórek organizmu) następuje fosforylacja czynników transkrypcyjnych takich jak STAT1, co w konsekwencji powoduje aktywację genów zależnych od interferonu (ISG; interferon-stimulated genes). ISG biorąc udział w odpowiedzi zapalnej oraz immunomodulacji hamują cykl replikacyjny i rozprzestrzenianie się wirusa m.in. poprzez spowalnianie metabolizmu komórkowego, wzrost wydzielania cytokin prozapalnych oraz zwiększenie ekspresji receptorów rozpoznających wzorce[38]. Z powodu szerokiego spektrum właściwości przeciwwirusowych- IFN typu I stosowane są w przypadku infekcji wirusowych spowodowanych przez nieznane dotychczas czynniki etiologiczne wykazując największe korzyści terapeutyczne gdy są wykorzystywane jako środek profilaktyczny albo na wczesnych etapach choroby [39]. W badaniach in vitro na linii komórkowej Vero E6 Lokugamage i wsp. [40] wykazali, że profilaktyczne stosowanie rekombinowanego IFN-a powoduje spadek intensywności replikacji SARS-CoV-2, natomiast w przypadku wirusa SARS-CoV nie zaobserwowano znaczących zmian. Powyższe różnice badacze tłumaczą wcześniej zaobserwowaną właściwością SARS-CoV do hamowania szlaków sygnalizacji komórkowej związanych z IFN, co objawiało się m.in. brakiem wpływu IFN na ilość ufosforylowanego STAT1 w komórkach gospodarza. Komórki zainfekowane SARS-CoV-2 traktowane profilaktycznie IFN miały zwiększoną ilość ufosforylowanego STAT1 w porównaniu do próby kontrolnej, co może sugerować, że wirus ten nie ma wpływu ww. szlaki [40]. Wyniki dotychczasowych badań klinicznych dotyczących skuteczności IFN w leczeniu infekcji koronawirusami MERS i SARS-CoV są niejednoznaczne i często wskazują na brak korzystnego wpływu na przebieg choroby. Większa wrażliwość komórek zakażonych SARS-CoV-2 na IFN wskazuje, że ta grupa związków okaże się być skuteczna w farmakoterapii COVID-19 [38].

\section{LOPINAWIR I RITONAWIR}

Lopinawir i ritonawir są inhibitorami proteazy HIV1 (ang. Human Immunodeficiency Virus Type 1). Lopinawir charakteryzuje się większą skutecznością w inhibicji HIV-1, natomiast ritonawir posiada dodatkową zdolność blokowania cytochromu p450 3A4, który odpowiada m.in za metabolizm lopinawiru. Połączenie ritonawiru z lopinawirem zwiększa zatem biodostępność tego drugiego. W badaniach in vitro wykazano, że lopinawir stosowany bez ritonawiru hamuje replikację MERS-CoV, SARS-CoV oraz hCoV-229E [41]. Lopinawir i ritonawir w połączeniu z ribawiryną był wcześniej stosowany podczas epidemii SARS-CoV i obniżał odsetek pacjentów, u których rozwijał się zespół ostrej niewydolności oddechowej. Skuteczność lopinawiru z ritona- wirem w leczeniu SARS-CoV-2 podlega dalszej ewaluacji. W badaniu in vitro przeprowadzonym przez Choy i wsp. [42] wykazano hamujące działanie samego lopinawiru na replikację SARS-CoV-2 przy EC $_{50}$ wynoszącym 26,1 $\mu \mathrm{M}$. Mniej obiecujące wyniki otrzymano $\mathrm{w}$ randomizowanym badaniu autorstwa Cao i wsp. [43]. przeprowadzonym na grupie 199 pacjentów z potwierdzoną infekcją SARS-CoV-2, w którym nie zaobserwowano istotnych korzyści z prowadzenia terapii skojarzonej lopinawir-ritonawir podawanych doustnie w dawkach odpowiednio $400 \mathrm{mg}$ i $100 \mathrm{mg}$ stosowanych dwa razy dziennie. Powyższe wyniki wskazują na konieczność dalszego przeprowadzenia badań w celu weryfikacji skuteczności omawianego połączenia. Do testowanych opcji terapeutycznych należy również terapia $\mathrm{z}$ zastosowaniem połączenia lopinawiru/ritonawiru $\mathrm{z}$ interferonem $\beta$. Przykładami są trwające obecnie badania kliniczne wykorzystujące ww. połączenie leków: badanie "MIRACLE" [44] skupiające się na MERS-CoV oraz badanie prowadzone przez Uniwersytet w Hongkogu [45] testujące wpływ leków na SARS-CoV-2.

\section{ROZPUSZCZALNA FRAKCJA ACE2}

Białko ACE2 posiada domenę znajdującą się na zewnątrz komórki, która stanowi m.in. receptor dla SARS-CoV-2 oraz domenę transbłonową, umożliwiającą zakotwiczenie całego białka w błonie komórkowej. Dzięki aktywności proteazy ADAM17 (ang. a disintegrin and metalloproteinase 17) ACE2 zostaje przecięte, co powoduje uwolnienie domeny pozakomórkowej do krwioobiegu (Ryc. 1B). Ta wolna frakcja ACE2 nazywana jest rozpuszczalną i jej małe stężenia są wykrywalne zarówno we krwi, jak i w moczu [46]. Battle i wsp. [47] w swojej pracy przypuszczają, że rozpuszczalna frakcja ACE2 (rACE2) mogłaby być potencjalnym lekiem na COVID-19. Przypuszczalny mechanizm działania miałby polegać na wiązaniu się rACE2 z wirusem SARS-CoV-2, co uniemożliwiałoby mu wiązanie się do ACE2 na komórkach gospodarza i dalszą infekcję. W badaniach iv vitro rACE2 połączony $\mathrm{z}$ fragmentem Fc immunoglobuliny (połączenie to ma za zadanie zwiększyć okres półtrwania związku w organizmie) wykazał zdolność do neutralizacji SARS-CoV-2 [48]. Na razie jednak nie ma wyników badań na modelach zwierzęcych oraz klinicznych, które pozwoliłyby ocenić skuteczność rACE2 w leczeniu COVID-19. Do testowanej grupy leków blokujących wejście wirusa do komórki gospodarza należą również przeciwciała skierowane przeciwko glikoproteinie S oraz inhibitor proteazy TMPRSS2 - mesylan kamostatu, które zostały dokładniej omówione w pracy przeglądowej napisanej przez Hoffman i wsp. [49].

\section{ANTAGONIŚCI RECEPTORA ANGIOTENSYNY II}

W badaniach na mysim modelu ostrego zapalenia płuc indukowanym przez aspirację kwasu oraz sepsę Imai i wsp. [50] zademonstrowali, że ACE2 ma działanie protekcyjne i chroni myszy przed ciężkim uszkodzeniem tego narządu. Osobniki, u których wyłączono gen Ace2 (kodujący ACE2), po wywołaniu zapalenia płuc cechowały się (w porównaniu do próby kontrolnej) gorszym rokowaniem i przebiegiem choroby, niższym stopniem utlenowania krwi, zwiększoną liczbą komórek zapalnych w tkance płucnej oraz masywniejszym obrzękiem płuc. Autorzy zasugerowali, że mecha- 


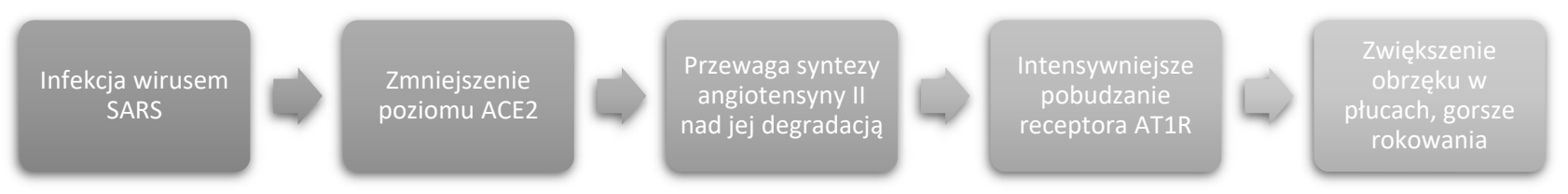

Rycina 2. Prawdopodobny wpływ wirusa SARS na ekspresję ACE 2 oraz przebieg choroby.

nizmem leżącym u podstaw ww. różnic było zaburzenie równowagi między tworzeniem, a rozpadem angiotensyny II odpowiednio przez ACE i ACE2. W tkance płucnej, na skutek obniżonej aktywności katalitycznej ACE2, nastąpiła kumulacja angiotensyny II. Konsekwencją tego było intensywniejsze pobudzenie receptora angiotensynowego typu 1 (AT1R) w naczyniach płucnych, co wpłynęło na zwiększenie ich przepuszczalności oraz ciśnienia hydrostatycznego generując przy tym obrzęk tkanki płucnej.

Wyniki uzyskane $\mathrm{w}$ badaniach na mysim modelu infekcji wirusem SARS-CoV przez Kuba i wsp. [51] sugerują, że interakcja pomiędzy białkiem $S$ wirusa SARS a ACE2 przyczynia się do obniżenia poziomu tego enzymu w tkance płucnej, co może być prawdopodobną przyczyną objawów płucnych u zakażonych pacjentów. Ze względu na duże podobieństwo białka S u SARS-CoV-2 i SARS-CoV, choroby wywoływane przez te wirusy mogą mieć podobny patomechanizm, a zatem zakłada się istotną w nim rolę ACE, ACE2 i angiotensyny II (Ryc. 2).

Antagoniści receptora angiotensyny II (ang. angiotensin receptor blocker; $\mathrm{ARB}$ ) to grupa leków powszechnie stosowana $\mathrm{w}$ terapii nadciśnienia tętniczego. Mechanizm działania ARB polega na blokowaniu AT1R, co uniemożliwia angio- tensynie II pełnienia swoich biologicznych funkcji takich jak wazokonstrykcja oraz retencja wody i sodu w organizmie (Ryc. 3). Dodatkowo, u chorych przyjmujących przewlekle olmesartan oraz losartan (leki z grupy ARB) wykazano zwiększoną ekspresję białka ACE2, które przekształca angiotensynę II $\mathrm{w}$ angiotensynę 1-7, która działając na receptor mas-R powoduje wazodylatację $[52,53]$.

Chociaż zwiększanie ekspresji białka ACE2 będącego receptorem dla wirusa SARS-CoV-2 wydaje się być nieintuicyjnym podejściem terapeutycznym, to ze względu na wyżej przytoczone badania ARB są rozpatrywane jako potencjalne leki w terapii COVID-19 [54]. Niestety, do tej pory brakuje danych klinicznych o wynikach leczenia COVID-19 u pacjentów przyjmujących ARB. Zaplanowano dotychczasowo dwa randomizowane kontrolowane badania kliniczne mające ocenić skuteczność codziennego, doustnego podawania losartanu $\mathrm{w}$ dawce $25 \mathrm{mg}$ dzienne w leczeniu COVID-19 u pacjentów wymagających hospitalizacji $(\mathrm{n}=200)$ [55] i nie wymagających hospitalizacji $(\mathrm{n}=478)$ [56].

\section{PODSUMOWANIE}

Mimo ogromu uwagi i działań poświęcanych walce $\mathrm{z}$ pandemią wirusa SARS-CoV-2 wiedza na jego temat na-

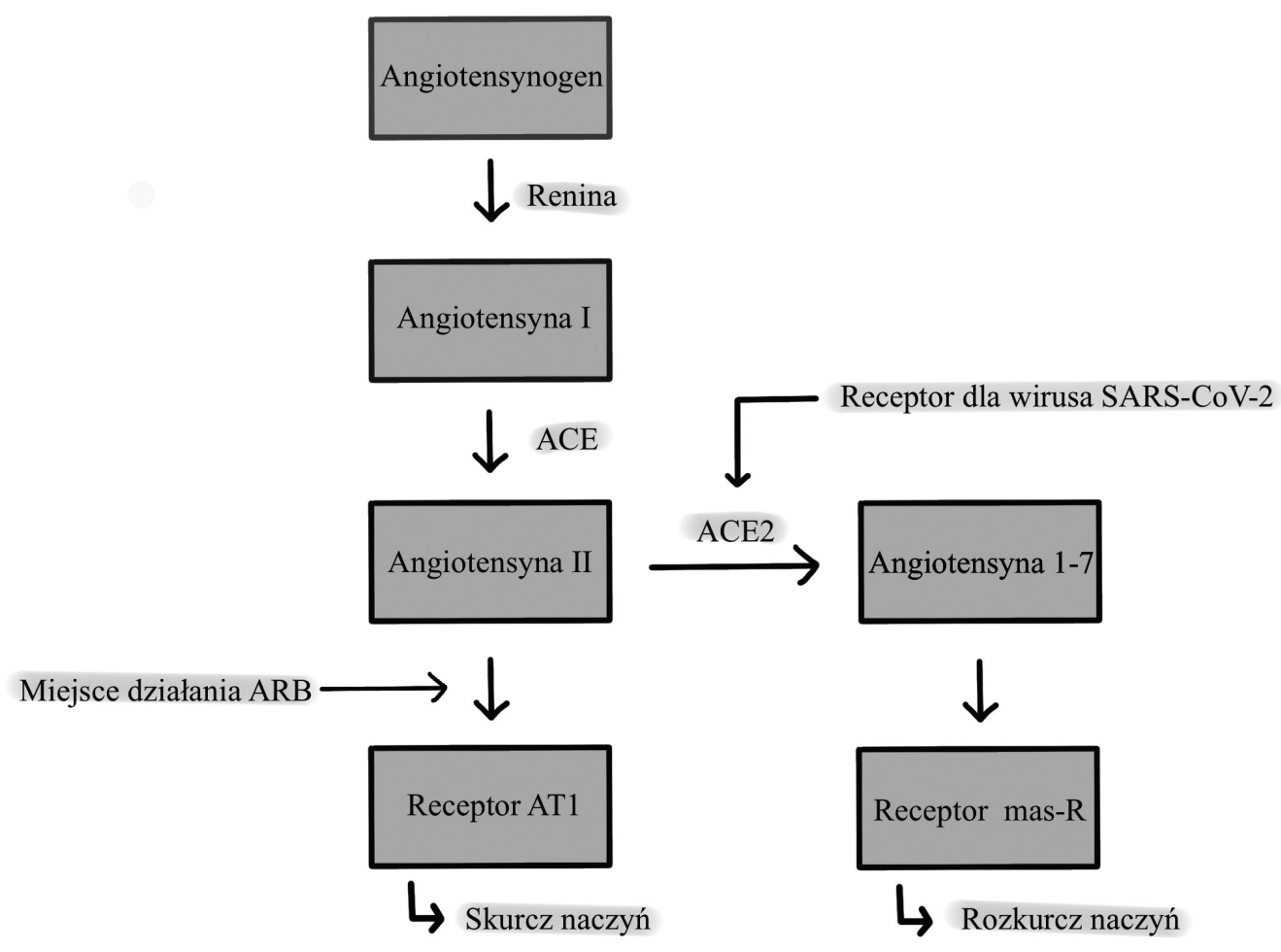

Rycina 3. Uproszczony schemat szlaków przekształceń angiotensynogenu i angiotensyny. 
dal pozostaje ograniczona. Skuteczne metody leczenia farmakologicznego ani szczepionka nie zostały dotychczas opracowane. Potencjalne leki wciąż są poddawane ewaluacji bądź oczekuje się na wyniki badań klinicznych z ich zastosowaniem. Największym z przedsięwzięć skupiających się na rozwoju opcji terapeutycznych jest badanie kliniczne "Solidarity" zapoczątkowane przez WHO pod koniec marca 2020 roku, które skupia się na ocenie terapii COVID-19 z użyciem: chlorochiny i hydroksychlorochiny, remdesiwiru, lopinawiru i ritonawiru oraz połączenia dwóch poprzednich z interferonem- $\beta$. Dodatkowo warto podkreślić, że większość badań odnośnie COVID-19 dotyczy chińskich pacjentów, dlatego dane te należy z ostrożnością odnosić do innych populacji. W tym trudnym okresie jako społeczeństwo powinniśmy stosować wszystkie koniecznie środki ostrożności, aby zapobiegać rozprzestrzenianiu się patogenu. Rosnąca liczba doniesień naukowych na temat wirusa stanowi optymistyczną prognozę na najbliższe miesiące, ponieważ im lepiej poznamy wirusa, tym skuteczniej będziemy mogli z nim walczyć.

\section{REFERENCJE}

1. Coronavirus disease 2019 (COVID-19) Situation Report-86 [Internet]. [cited 2020 Apr 16]. Available from: https://www.who.int/teams/ risk-communication/infodemic-management

2. Guo Y-R, Cao Q-D, Hong Z-S, Tan Y-Y, Chen S-D, Jin H-J, Tan KS, Wang DY, Yan Y (2020) The origin, transmission and clinical therapies on coronavirus disease 2019 (COVID-19) outbreak - an update on the status. Mil Med Res 7:11

3. Gaunt ER, Hardie A, Claas ECJ, Simmonds P, Templeton KE (2010) Epidemiology and clinical presentations of the four human coronaviruses 229E, HKU1, NL63, and OC43 detected over 3 years using a novel multiplex real-time PCR method. J Clin Microbiol 48: 2940-7

4. Song Z, Xu Y, Bao L, Zhang L, Yu P, Qu Y, Zhu H, Zhao W, Han Y, Qin C (2019) From SARS to MERS, thrusting coronaviruses into the spotlight. Viruses 11: pii: E59

5. Nassar MS, Bakhrebah MA, Meo SA, Alsuabeyl MS, Zaher WA (2018) Middle East Respiratory Syndrome Coronavirus (MERS-CoV) infection: epidemiology, pathogenesis and clinical characteristics. Eur Rev Med Pharmacol Sci 22: 4956-61

6. Cui J, Li F, Shi ZL (2019) Origin and evolution of pathogenic coronaviruses. Nat Rev Microbiol 17: 181-92

7. Khan S, Siddique R, Shereen MA, Ali A, Liu J, Bai Q, Bashir N, Xue $M$ (2020) The emergence of a novel coronavirus (SARS-CoV-2), their biology and therapeutic options. J Clin Microbiol 58: pii: e00187-20

8. Lu R, Zhao X, Li J, Niu P, Yang B, Wu H, et al. (2020) Genomic characterisation and epidemiology of 2019 novel coronavirus: implications for virus origins and receptor binding. Lancet 395: 565-574

9. van Doremalen N, Bushmaker T, Morris DH, Holbrook MG, Gamble A, Williamson BN, et al. (2020) Aerosol and Surface Stability of SARS-CoV-2 as Compared with SARS-CoV-1. N Engl J Med 382: 1564-156

10. Chan JFW, Kok KH, Zhu Z, Chu H, To KKW, Yuan S, et al. (2020) Genomic characterization of the 2019 novel human-pathogenic coronavirus isolated from a patient with atypical pneumonia after visiting Wuhan. Emerg Microbes Infect 9: 221-236

11. Walls AC, Park Y-J, Tortorici MA, Wall A, McGuire AT, Veesler D (2020) Structure, function, and antigenicity of the SARS-CoV-2 spike glycoprotein. Cell 181: 281-292.e6

12. Anguiano L, Riera M, Pascual J, Soler MJ (2017) Circulating ACE2 in Cardiovascular and Kidney Diseases. Curr Med Chem 24: 3231-3241

13. Zhao Y, Zhao Z, Wang Y, Zhou Y, Ma Y, Zuo W (2020) Single-cell RNA expression profiling of ACE2, the putative receptor of Wuhan 2019nCov. bioRxiv DOI: 10.1101/2020.01.26.919985

14. Danilczyk U, Penninger JM (2006) Angiotensin-converting enzyme II in the heart and the kidney. Circ Res 98: 463-471
15. Gu J, Han B, Wang J (2020) COVID-19: Gastrointestinal manifestations and potential fecal-oral transmission. Gastroentorology 158: 1518-1519

16. Fehr AR, Perlman S (2015) Coronaviruses: An overview of their replication and pathogenesis. Coronaviruses 1282: 1-23

17. Zu ZY, Jiang M Di, Xu PP, Chen W, Ni QQ, Lu GM, et al. Coronavirus Disease 2019 (COVID-19): A Perspective from China. Radiology DOI: 10.1148/radiol.2020200490

18. Loeffelholz MJ, Tang Y-W (2020) Laboratory diagnosis of emerging human coronavirus infections - the state of the art. Emerg Microbes Infect 9: 747-756

19. Li Z, Yi Y, Luo X, Xiong N, Liu Y, Li S, et al. (2020) Development and clinical application of a rapid IgM-IgG combined antibody test for SARS-CoV-2 infection diagnosis. J Med Virol DOI: 0.1002/jmv.25727

20. Han R, Huang L, Jiang H, Dong J, Peng H, Zhang D (2020) Early clinical and CT manifestations of coronavirus disease 2019 (COVID-19) Pneumonia. AJR Am J Roentgenol 17: 1-6

21. Gozes O, Frid-Adar M, Greenspan H, Browning PD, Bernheim A Siegel E (2020) Rapid AI development cycle for the coronavirus (COVID-19) pandemic: initial results for automated detection \& patient monitoring using deep learning CT image analysis. arXiv:2003.05037

22. Lai CC, Shih TP, Ko WC, Tang HJ, Hsueh PR (2020) Severe acute respiratory syndrome coronavirus 2 (SARS-CoV-2) and coronavirus disease-2019 (COVID-19): The epidemic and the challenges. Int J antimicrob Agents 55(3):105924

23. Chloroquine. LiverTox: Clinical and research information on drug-induced liver injury. National Institute of Diabetes and Digestive and Kidney Diseases

24. Savarino A, Boelaert JR, Cassone A, Majori G, Cauda R (2003) Effects of chloroquine on viral infections: An old drug against today's diseases? Lancet Infect Dis 3: 722-727

25. Li R, Lin H, Ye Y, Xiao Y, Xu S, Wang J, et al. (2018) Attenuation of antimalarial agent hydroxychloroquine on TNF- $\alpha$-induced endothelial inflammation. Int Immunopharmacol 63: 261-269

26. Wang M, Cao R, Zhang L, Yang X, Liu J, Xu M, et al. (2020) Remdesivir and chloroquine effectively inhibit the recently emerged novel coronavirus (2019-nCoV) in vitro. Cell Research 30: 269-271

27. Koreeda A, Yonemitsu K, Kohmatsu H, Mimasaka S, Ohtsu Y, Oshima T, et al. (2020) Immunohistochemical demonstration of the distribution of chloroquine (CQ) and its metabolites in CQ-poisoned mice. Arch Toxicol 81(7): 471-478

28. Yao X, Ye F, Zhang M, Cui C, Huang B, Niu P, et al. (2020) In Vitro Antiviral activity and projection of optimized dosing design of hydroxychloroquine for the treatment of severe acute respiratory syndrome coronavirus 2 (SARS-CoV-2). Clin Infect Dis DOI: 10.1093/cid/ciaa237

29. Gao J, Tian Z, Yang X (2020) Breakthrough: Chloroquine phosphate has shown apparent efficacy in treatment of COVID-19 associated pneumonia in clinical studies. Biosci Trends 14(1):72-73

30. Agostini ML, Andres EL, Sims AC, Graham RL, Sheahan TP, Lu X, et al. (2018) Coronavirus susceptibility to the antiviral remdesivir (GS5734 ) is mediated by the viral polymerase and the proofreading exoribonuclease. mBio 9: pii: e00221-18

31. Al-Tawfiq JA, Al-Homoud AH, Memish ZA (2020) Remdesivir as a possible therapeutic option for the COVID-19. Travel Med Infect Dis 5: 101615

32. Tchesnokov EP, Feng JY, Porter DP, Götte M (2019) Mechanism of inhibition of ebola virus RNA-dependent RNA polymerase by remdesivir. Viruses 11: pii: E326

33. Wang M, Cao R, Zhang L, Yang X, Liu J, Xu M, et al. (2020) Remdesivir and chloroquine effectively inhibit the recently emerged novel coronavirus (2019-nCoV) in vitro. Cell Research 30: 269

34. Holshue ML, DeBolt C, Lindquist S, Lofy KH, Wiesman J, Bruce H, et al. (2020) First Case of 2019 Novel Coronavirus in the United States. N Engl J Med 382: 929-936

35. Severe 2019-nCoV Remdesivir RCT. ClinicalTrials.gov: NCT04257656

36. Mild/Moderate 2019-nCoV Remdesivir RCT. - Full Text View - ClinicalTrials.gov: NCT04252664 
37. Al-Tawfiq JA, Al-Homoud AH, Memish ZA (2020) Remdesivir as a possible therapeutic option for the COVID-19. Travel Med Infect Dis 5: 101615

38. Sallard E, Lescure F-X, Yazdanpanah Y, Mentre F, Peiffer-Smadja N, C-20-15 DisCoVeRy French Steering Committee (2020) Type 1 interferons as a potential treatment against COVID-19. Antiviral Res 178: 104791

39. Totura AL, Bavari S (2019) Broad-spectrum coronavirus antiviral drug discovery. Exp Op on Drug Disc14: 397-412

40. Lokugamage KG, Hage A, Schindewolf C, Rajsbaum R, Menachery VD (2020) SARS-CoV-2 is sensitive to type I interferon pretreatment. bioRxiv DOI: 10.1101/2020.03.07.982264

41. De Wilde AH, Jochmans D, Posthuma CC, Zevenhoven-Dobbe JC, Van Nieuwkoop S, Bestebroer TM, et al. (2014) Screening of an FDA-approved compound library identifies four small-molecule inhibitors of Middle East respiratory syndrome coronavirus replication in cell culture. Antimicrob Agents Chemother 58: 4875-4884

42. Forsythe P, Bienenstock J, Kunze WA (2014) Vagal pathways for microbiome-brain-gut axis communication. Adv Exp Med Biol 817: 115133

43. Cao B, Wang Y, Wen D, Liu W, Wang J, Fan G, et al. (2020) A Trial of Lopinavir-Ritonavir in Adults Hospitalized with Severe Covid-19. N Engl J Med DOI: 10.1056/NEJMoa2001282

44. Arabi YM, Alothman A, Balkhy HH, Al-Dawood A, AlJohani S, Al Harbi S, et al. (2018) Treatment of Middle East Respiratory Syndrome with a combination of lopinavir-ritonavir and interferon- $\beta 1 \mathrm{~b}$ (MIRACLE trial): study protocol for a randomized controlled trial. Trials 19: 81

45. Lopinavir/Ritonavir, Ribavirin and IFN-beta Combination for $\mathrm{nCoV}$ Treatment. ClinicalTrials.gov: NCT04276688

46. Lambert DW, Yarski M, Warner FJ, Thornhill P, Parkin ET, Smith AI, et al. (2005) Tumor necrosis factor-a convertase (ADAM17) mediates regulated ectodomain shedding of the severe-acute respiratory syn- drome-coronavirus (SARS-CoV) receptor, angiotensin-converting enzyme-2 (ACE2). J Biol Chem 280: 30113-30119

47. Batlle D, Wysocki J, Satchell K (2020) Soluble angiotensin-converting enzyme 2: a potential approach for coronavirus infection therapy? Clin Sci (Lond) 134: 543-545

48. Lei C, Fu W, Qian K, Li T, Zhang S, Ding M, et al. (2020) Potent neutralization of 2019 novel coronavirus by recombinant ACE2-Ig. bioRxiv DOI: $10.1101 / 2020.02 .01 .929976$

49. Hoffmann M, Kleine-Weber H, Schroeder S, Krüger N, Herrler T, Erichsen S, et al.(2020) SARS-CoV-2 Cell entry depends on ACE2 and TMPRSS2 and is blocked by a clinically proven protease inhibitor. Cell 181: 271-280.e8

50. Imai Y, Kuba K, Rao S, Huan Y, Guo F, Guan B, et al. (2005) Angiotensin-converting enzyme 2 protects from severe acute lung failure. Nature 436: 112-116

51. Kuba K, Imai Y, Rao S, Gao H, Guo F, Guan B, et al. (2005) A crucial role of angiotensin converting enzyme 2 (ACE2) in SARS coronavirus-induced lung injury. Nat Med 11: 875-879

52. Furuhashi M, Moniwa N, Mita T, Fuseya T, Ishimura S, et al. (2015) Urinary angiotensin-converting enzyme 2 in hypertensive patients may be increased by olmesartan, an angiotensin II receptor blocker. Am J Hypertens 28: 15-21

53. Klimas J, Olvedy M, Ochodnicka-Mackovicova K, Kruzliak P, Cacanyiova S, Kristek F, et al. (2015) Perinatally administered losartan augments renal ACE2 expression but not cardiac or renal Mas receptor in spontaneously hypertensive rats. J Cell Mol Med 19: 1965-1974

54. Gurwitz D (2020) Angiotensin receptor blockers as tentative SARS-CoV-2 therapeutics. Drug Dev Res DOI: 10.1002/ddr.21656

55. Randomized controlled trial of losartan for patients with COVID-19 requiring hospitalization. ClinicalTrials.gov: NCT04312009

56. Randomized controlled trial of losartan for patients with COVID-19 not requiring hospitalization. ClinicalTrials.gov: NCT04311177

\section{Characteristics of SARS-CoV-2 and potential pharmacological treatment}

\section{Leon Pawlik, Emilian Śpiołek, prof. dr. hab Jakub Fichna, mgr inż. Aleksandra Tarasiuk ${ }^{\varpi}$}

Department of Biochemistry, Faculty of Medicine, Medical University of Lodz, Łódź, Poland

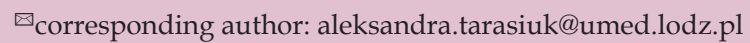

Keywords: SARS-CoV-2, COVID-19, chloroquine, ribavirin, angiotensin II receptor blockers

\section{SUMMARY}

In December 2019 in Wuhan, China the first cases of previously unknown, coronaviral infection-induced pneumonia have been reported. The new virus SARS-CoV-2 (Severe Acute Respiratory Syndrome Coronavirus 2) was named after SARS-CoV due to their similarities and the disease caused by the pathogen is COVID-19 (Coronavirus Disease 2019). On 11 March 2020 WHO (World Health Organization) defined the rapidly increasing number of incidents of COVID-19 as a pandemic. In this review we will present recent information about the SARS-CoV-2 focusing on the origin, clinical picture, diagnostic methods, structure, replication cycle of SARS-CoV-2 and potential pharmaceutical measures against COVID-19. 